\title{
Bcl2 and c-erbB-3 as Prognostic Markers of Hepatocellular Carcinoma
}

\author{
Hanan Fouad ${ }^{(1)}$ \& Ahmed Bahgat Eldemery ${ }^{(2)}$ \\ Medical Biochemistry Department, Faculty of Medicine, Cairo University ${ }^{(1)}$, \\ Biochemistry Department, Faculty of Medicine, October 6 University ${ }^{(2)}$.
}

\begin{abstract}
The present study was conducted to evaluate gene expression profile of c-erbB-3 and bcl2 in hepatocellular carcinoma patients (HCC) with and without associated hepatitis $C$ virus (HCV) infection. Forty eight subjects were included in the study and divided equally into 2 groups: Group 1 involved HCC subjects with associated HCV infection and group 2 involved HCC subjects without HCV associated infection. Adjacent para-cancerous tissues were examined as control samples. Correlations with various clinico-pathological parameters of the tumor were assessed; stage, tumor size, intra-hepatic metastasis and carcinoma differentiation. c-erbB-3 oncogene was expressed in $83.33 \%$ (40/48) of total HCC samples and in $31.25 \%$ (15/48) of the noncancerous lesions. c-erbB-3 was expressed in $87.5 \%$ (21/24) of HCC samples with associated HCV infection and in 79.16\% (19/24) of HCC without associated HCV infection. Gene expression of c-erbB-3 was significantly correlated to the clinico-pathological parameters of the tumor. As regards bcl2 gene expression, the gene was expressed in $20.8 \%$ (10/48) of total HCC samples and in the paracancerous lesions. Bcl2 was expressed in 20.8\% (5/24) of HCC samples with and without HCV associated infection. Gene expression of bcl2 did not show significant correlations to the clinico-pathological parameters of the tumor. In conclusion, expression profile of c-erbB-3 in hepatocellular carcinoma patients could be used as a prognostic molecular marker in HCC.
\end{abstract}

Key Words: Hepatocellular carcinoma; bcl2; c-erbB-3

\section{INTRODUCTION}

Hepatocellular carcinoma (HCC) is one of the most common causes of death from cancer in several regions in the world including Egypt. In spite of enormous efforts to improve clinical treatment, HCC remains a major carcinoma with high mortality. Poor differentiation, larger size, portal invasion and intra-hepatic metastasis are known to shorten disease free survival with that carcinoma. One of the most prominent parameters in evaluation of the biological aggressiveness of carcinoma is the investigation of cell behavior. Growth factor receptors with tyrosine kinase activity are known to contribute greatly to the regulation of cell behavior such as cell growth, proliferation and mortality ${ }^{[1,2]}$. The type I family of growth factor receptors is the most prominent and is recognized as a proto-oncogene family. The family includes the epidermal growth factor receptor 
(EGFR) family of receptor tyrosine kinases that includes cell erythroblastic leukemia viral oncogene homolog 3 (c-erbB-3) $)^{[3,4]}$. When specific ligands bind to a receptor of the family, the receptor is activated by phosphorylation of the tyrosine residue in the molecule ${ }^{[1]}$. It then forms a dimer with another receptor of that family, causing activation by transphosphorylation which contributes to a variety of growth signal transductions ${ }^{[5]}$. These receptors share high sequence identity with each other and are coexpressed in various combinations in neoplasms. Thus far, of the four receptors of the family, the expression of c-erbB-3 has been investigated in various neoplasms, including malignancies of the liver and biliary tract ${ }^{[6-8]}$.

Although the mechanisms of hepatocellular carcinogenesis are not yet expounded, alterations of some oncogenes, and aberrant DNA methylation and hypermethylation have been reported in hepatocarcinogenesis $^{[9]}$. On the other hand, hepatitis $\mathrm{C}$ virus (HCV) infection was proved to be closely linked to the development of HCC and HCV may be the second important factor in association with HCC-etiology ${ }^{[10-12]}$. The molecular mechanisms involved in hepato-carcinogenesis of $\mathrm{HCV}$ remain poorly understood. Up to now, many authors believe that HCV can not directly change the structure of the host genes like hepatitis B virus by integration because $\mathrm{HCV}$ is a ribonucleic acid (RNA) virus. Therefore, the effect of $\mathrm{HCV}$ on factors of controlling cell cycle, apoptosis and onccogenes is an important field in the hepatocarcinogenesis studies ${ }^{[12,13]}$.

On the other hand, The B-cell lymphoma 2 (bcl-2) gene family is a group of apoptosis-related genes which are studied extensively at present ${ }^{[14]}$. Accumulated reports show that there is a high-level expression of bcl-2 in many tumor tissues ${ }^{[15,16]}$. Primary $\mathrm{HCC}$ is a very common malignant tumor in Egypt ${ }^{[17]}$. Yildiz et al. ${ }^{[17]}$,also, stated that bcl-2 is highly expressed in $\mathrm{B}$ and $\mathrm{C}$ hepatitis and hepatocellular carcinomas. The high incidence of bcl-2 activity in the nonneoplastic liver parenchyma of the HCC cases suggest that bcl-2 activation may be involved in the development of at least some cases of hepatocellular carcinoma.

The present study was conducted to evaluate gene expression profile $c$ erbB-3 and bcl2 of in hepatocellular carcinoma patients (HCC) with and without HCV associated infection. Correlations with various clinicpathological parameters of the tumor were assessed to find whether the expression profile of the studied genes could be used as prognostic markers in hepatocellular carcinoma patients.

\section{MATERIAL \& METHODS}

Tissue specimens

$10 \%$ buffered formalin-fixed paraffin-embedded blocks of $\mathrm{HCC}$ were prepared from 48 patients who had undergone surgery for HCC in Kasr -elaini hospital pathology archeive -Faculty of Medicine, Cairo University. Informed consent was obtained from each patient. The clinico-pathological characteristics of the patients were shown in Table 1 . 
Gene expression profile of $c$-erb-B3 and bcl2 in HCC samples ${ }^{[18,19]}$,

Total RNA was extracted using the easy ribonucleic acid (RNeasy) Purification Reagent (Promega, Madison, WI, USA), and then a sample $(1 \mu \mathrm{g})$ was reverse transcribed with Moleny-Murine Leukemia virus (M-MLV) reverse transcriptase (RT) for $30 \mathrm{~min}$ at $42^{\circ} \mathrm{C}$ in the presence of oligo deoxynucleotides (oligo-dT) primer. Polymerase chain reaction (PCR) was performed using primers specified on Table 2. PCR was performed for 45 cycles, with each cycle consisting of denaturation at $95^{\circ} \mathrm{C}$ for 30 seconds, annealing at $58.5^{\circ} \mathrm{C}$ to $59.5^{\circ} \mathrm{C}$ as specified for each primer pairs for $30 \mathrm{sec}$ and elongation at $72^{\circ} \mathrm{C}$ for $1 \mathrm{~min}$, with an additional 10 -min incubation at $72^{\circ} \mathrm{C}$ after completion of the last cycle. To exclude the possibility of contaminating genomic DNA, PCRs were also run without RT. Beta actin gene expression was assessed as a positive control housekeeping gene. The PCR product was separated by electrophoresis through a $1 \%$ agarose gel, stained, and photographed under ultraviolet light.

Semiquantification of PCR products by Gel documentation

RT-PCR of the gene products was semiquantified using densitometry gel documentation

(BioDocAnalyze, system Biometra, the manufacturer's specifications of the software. The amounts of PCR products were evaluated according to the relative intensity of the studied genes and beta actin bands by using the computed densitometry assay of the Biometra BioDoc Analyze System.

\section{Statistical analyses}

Values were expressed in (Fig.4) The chi-squared test and KruskalWallis test followed by Dunn's test of multiple comparisons were employed for analyses of the relationship between the expression of the genes and various clinicopathological parameters. $p$ value less than 0.05 was considered to be statistically significant. All of the statistical analyses were performed using statistical package for social studies (SPSS) version 10 software (SPSS,Chicago, IL).

\section{RESULTS}

In the present study, c-erbB-3 oncogene was highly expressed all HCC samples as compared to the adjacent paracancerous lesions (Fig.1) whereas bcl-2 gene showed equal expression in HCC samples as compared to paracancerous tissues (Fig. 2). Beta actin gene was expressed in all samples (Fig. 3).

Moreover, c-erbB3 was overexpressed in of HCC samples with $\mathrm{HCV}$ associated infection as compared to $\mathrm{HCC}$ without $\mathrm{HCV}$ associated infection (Fig. 4) whereas bcl-2 genes were equally expressed in HCC samples with or without HCV associated infection (Fig. 5).

Furthermore, gene expression of c-erbB-3 showed significant positive correlation to the clinic-pathological parameters of the tumor, whereas, gene expression of bcl2 did not show any significant correlations to the clinico-pathological parameters of the tumor (Table 3). 


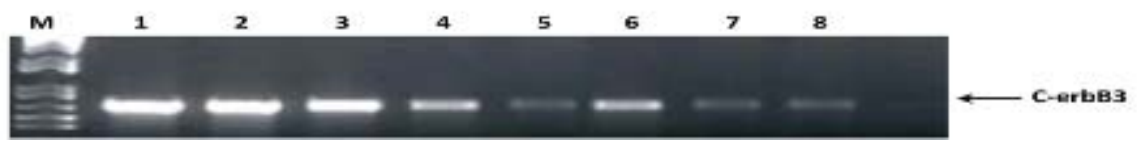

Figure 1. PCR product of c-erbB-3 gene (348 bp)

Lane 1 : PCR marker (100 bp ladder)

Lanes 1-2: HCC samples with HCV associated infection

Lanes 3-4: HCC samples without $\mathrm{HCV}$ associated infection

Lanes 5-8: Adjacent para-cancerous tissues

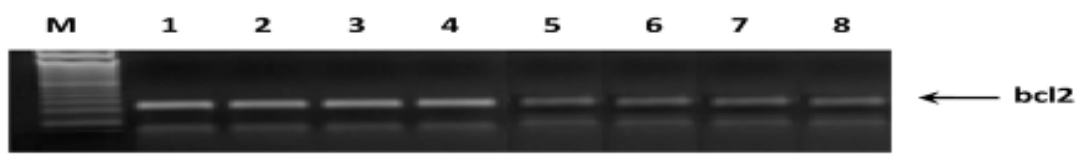

Figure 2. PCR product of bcl2 gene $(220 \mathrm{bp})$

Lane 1 : PCR marker (100 bp ladder)

Lanes 1-2 : HCC tissues with HCV associated infection

Lanes 3-4 : HCC tissues without HCV associated infection

Lanes 5-8 : Adjacent paracancerous tissues

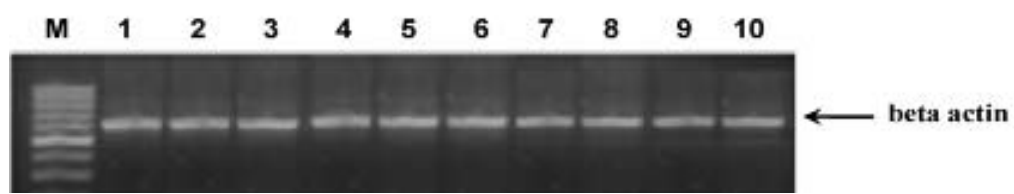

Figure 3. PCR product of beta actin gene (397 bp )

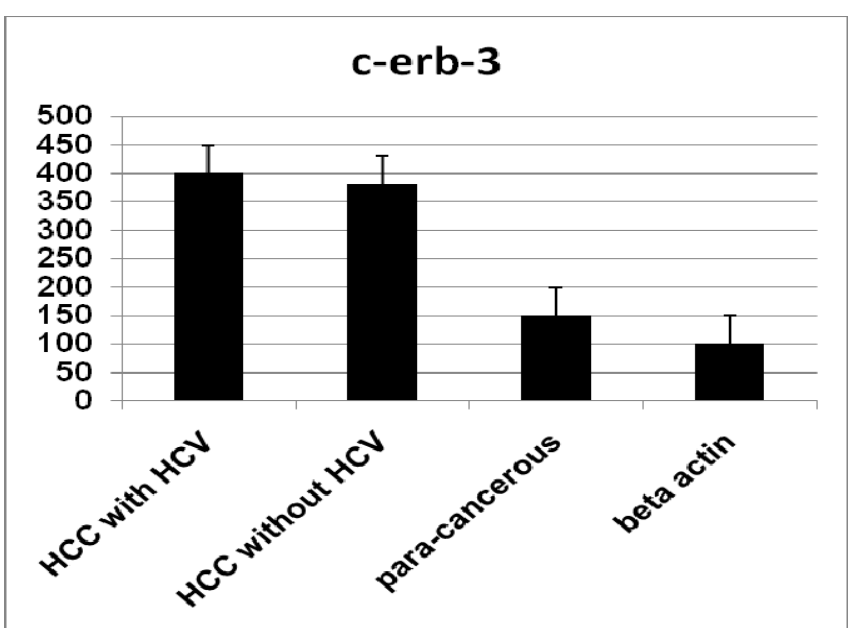

Figure 4. c-erb-B3 gene gel documentation by semiquantitative RT-PCR. density ratios. The gene was calculated in relation to the internal standard beta-actin and expressed as means +SEM. (* Significant difference with beta actin). 


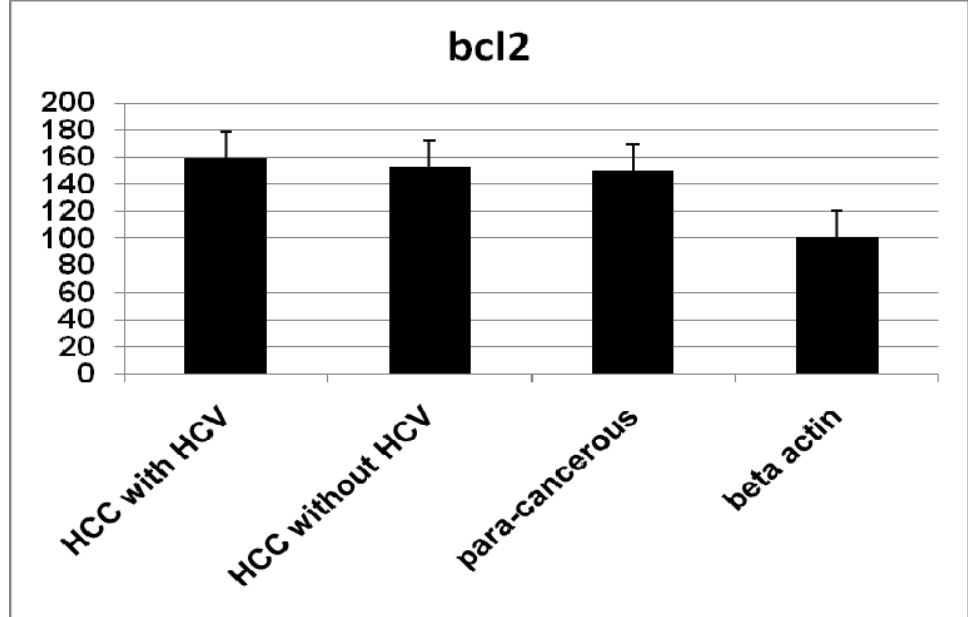

Figure 5. bcl2 gene documentation by semiquantitative RT-PCR. density ratios.

Table1. clinico-pathological characteristics of the patients

\begin{tabular}{|l|l|l|}
\hline Age (years) & $\mathbf{6 2 . 3} \pm \mathbf{7 . 5}$ & Number of subjects \\
\hline Gender & Male & 38 \\
& female & 10 \\
\hline HCV & +ve by PCR & 24 \\
& -ve by PCR & 24 \\
\hline Tumor stage & $<$ III & 30 \\
& $>$ III & 18 \\
\hline Tumor size & $>5 \mathrm{~cm}$ & 20 \\
& $<5 \mathrm{~cm}$ & 28 \\
\hline Intrahepatic metastasis & with & 17 \\
& without & 31 \\
\hline Carcinoma differentiation & poor & 16 \\
& moderate or well & 32 \\
\hline
\end{tabular}

Table 2. The oligonucleotide primers sequence of studied genes

\begin{tabular}{|c|c|c|c|}
\hline & Primer sequence & $\begin{array}{l}\text { Annealing } \\
\text { temperature }\end{array}$ & $\begin{array}{l}\text { Product } \\
\text { size }\end{array}$ \\
\hline c-erbB-3 & $\begin{array}{l}\text { Forward primer: 5'- GCCTGGACTTGGAAGGCACCTG -3' } \\
\text { Reverse primer: } 3 \text { '-GAGCCACAGAGACCGCGTGA-5' } \\
\text { GenBank® Accession Number: GenBank: Z23134.1 }\end{array}$ & $58.5^{\circ} \mathrm{C}$ & 348 bp \\
\hline $\mathrm{Bcl} 2$ & $\begin{array}{l}\text { Forward primer: 5' CGTCAACCGGGAGATGTCGCC 3' } \\
\text { Reverse primer:3'TGATTTTATTTCGCCGGCTCCACAG5' } \\
\text { GenBank® Accession Number: NM 000657.2 }\end{array}$ & $59^{\circ} \mathrm{C}$ & $220 \mathrm{bp}$ \\
\hline $\mathrm{B}$ actin & 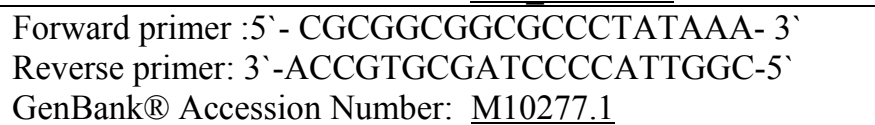 & $59.5^{\circ} \mathrm{C}$ & $397 \mathrm{bp}$ \\
\hline
\end{tabular}


Table 3. Correlations between the expression of erbB-3 and bcl2 genes and various clinic-pathological features of HCC subjects

\begin{tabular}{|c|c|c|c|c|}
\hline 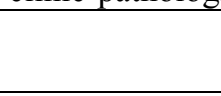 & es & $\begin{array}{l}\text { Number of } \\
\text { subjects }\end{array}$ & $\begin{array}{l}\text { Correlations } \\
\text { with c-erb-B3 } \\
\end{array}$ & $\begin{array}{l}\text { Correlations } \\
\text { with bcl2 }\end{array}$ \\
\hline Tumor stage & $\begin{array}{ll}> & \text { III } \\
< & \text { III } \\
\end{array}$ & $\begin{array}{l}18 \\
30 \\
\end{array}$ & $\mathrm{p}<0.001$ & NS \\
\hline Tumour size & $\begin{array}{l}>5 \mathrm{~cm} \\
<5 \mathrm{~cm}\end{array}$ & $\begin{array}{l}20 \\
28 \\
\end{array}$ & N.S. & NS \\
\hline $\begin{array}{l}\text { Intrahepatic } \\
\text { metastasis }\end{array}$ & $\begin{array}{l}\text { With } \\
\text { without }\end{array}$ & $\begin{array}{l}17 \\
31 \\
\end{array}$ & $\mathrm{p}<0.01$ & NS \\
\hline $\begin{array}{l}\text { Carcinoma } \\
\text { differentiation }\end{array}$ & $\begin{array}{l}\text { poor } \\
\text { moderate or well }\end{array}$ & $\begin{array}{l}16 \\
32 \\
\end{array}$ & $\mathrm{p}<0.001$ & NS \\
\hline
\end{tabular}

\section{DISCUSSION}

In the present study, c-erbB-3 oncogene was highly expressed all HCC samples as compared to the adjacent para-cancerous lesions. Moreover, c-erbB3 was overexpressed in cases of $\mathrm{HCC}$ samples with $\mathrm{HCV}$ associated infection as compared to $\mathrm{HCC}$ without $\mathrm{HCV}$ associated infection. Gene expression of c-erbB-3 was significantly correlated to the clinic-pathological parameters of the tumor. Similar studies have been performed on a few other carcinomas. For example, Sanidas et al. ${ }^{[20]}$ demonstrated that the c-erbB-3 protein was always expressed in both gastric carcinoma and the adjacent mucosa, but the expression level was usually higher in the carcinoma. Travis et al., ${ }^{[21]}$ observed that breast carcinoma expressed c-erbB-3 more intensely and diffusely than the adjacent normal glands which were usually weakly or moderately positive for that protein. Haugen et al. ${ }^{[22]}$ showed that normal follicles of the thyroid were all negative for c-erbB-3, whereas all types of thyroid carcinoma expressed that protein with very high incidence. The results of these studies including ours are similar in that they show cerbB-3 expression to be more diffuse and/or more intense in the carcinoma nest than in normal or benign lesions ${ }^{[23,24]}$. Our study also showed that c-erbB-3 expression in HCC was significantly related to some important markers of carcinoma progression, which are also predictors of recurrence, such as stage, tumor size, intrahepatic metastasis and carcinoma differentiation. Furthermore, c-erbB-3 itself, to some extent, affects diseasefree survival as reported in several studies $^{[25-27]}$.

To our knowledge there is no previous study conducted to evaluate the role of c-erb-B3 in liver tissue with hepatitis $\mathrm{C}$ virus nor in $\mathrm{HCV}$ associated HCC. However, El Bassuoni et al. ${ }^{[28]}$ reported that the elevated expression of another member of the c-erbB family of oncogenes (C-erbB-2) in $\mathrm{HCV}$ related chronic liver disease may reflect preneoplastic liver cell proliferation, cellular necrosis associated with chronic liver disease or $\mathrm{HCV}$ 
carcinogens which enhance malignant transformation.

As regards bcl 2 gene expression, the gene was expressed to an equal extent in all HCC samples and in all para-cancerous lesions. $\mathrm{Bcl} 2$ was equally expressed in HCC samples with and without associated $\mathrm{HCV}$ infection. Gene expression of bcl2 did not show significant positive correlation to the clinic-pathological parameters of the tumor ${ }^{[29,30]}$

Also, Yang et al. ${ }^{[29]}$ stated that the expression of $\mathrm{Bcl}-2$ protein in most tumor tissues is stronger than that in the tissues of origin. Nevertheless, most studies have demonstrated that HCC tissues do not express or have only a low positive rate of $\mathrm{Bcl}-2$ protein. Moreover, sometimes the positive rate of $\mathrm{Bcl}-2$ in HCC tissues was lower than that in the non-tumor liver tissues immediately adjacent to HCC tissues ,the mechanism of that phenomenon is still unclear. There may be specific characteristics of the regulation of $\mathrm{Bcl}-2$ in HCC. As regards HCC samples with hepatitis $\mathrm{C}$ virus, results of the present study coincided with the study of Tsamandas et al. ${ }^{[31]}$ who found bcl2 expression in liver biopsies with hepatitis $\mathrm{B}$ or $\mathrm{C}$ viruses. Moreover, Yildiz et al. ${ }^{[17]}$ studied Bcl2 gene expression in $\mathrm{B}$ and $\mathrm{C}$ hepatitis and hepatocellular carcinomas. The authors stated that no causative relation between bcl-2 positivity and hepatocellular carcinoma could be implied, however the high incidence of bcl-2 activity in the non-neoplastic liver parenchyma of the HCC cases suggests that bcl-2 activation may be involved in the development of at least some cases of hepatocellular carcinoma. Case control and/or prospective studies are needed to show whether bcl-2 positivity in a chronic hepatitis case has a predictive value for the development of hepatocellular carcinoma.

In conclusion, c-erbB-3 gene was over-expressed in HCC samples whereas, c-erbB-3 gene showed significant correlations to the clinicopathological parameters of the subjects, whereas, bcl 2 did not show any correlation to the clinicopathological parameters. Gene expression profile of $c$-erb-B3 could be used as a prognostic molecular marker in HCC.

\section{REFERENCES}

1. Ullrich A, Schlessinger J.: Signal transduction by receptors with tyrosine kinase activity. Cell. 1990; 61: 203-12.

2. Cantley LC, Auger KR, Carpenter C, Duckworth B, Graziani A, Kapeller R, et al. Oncogenes and signal transduction. Cell. 1991; 64: 281302.

3. Kraus MH, Issing W, Miki T, Popescu NC, Aaronson SA.: Isolation and characterisation of c-erbB-3, a third member of the erbB/epidermal growth factor receptor family; evidence of overexpression in a subset of human mammary tumours. Proc Natl Acad Sci USA. 1989; 86: 9193-97.

4. Plowman GD, Culouscou J-M, Whitney GS, Green JM, Carlton GW, Foy L, et al.: Ligand-specific activation of HER4/p180, a fourth member of 
the epidermal growth factor receptor family. Proc Natl Acad Sci USA. 1993; 90: 1746- 50.

5. Pinkas-Kramarski R, Soussan L, Waterman H, Levkowitz G, Alroy I, Klapper L, et al. Diversification of $\mathrm{Neu}$ differentiation factor and epidermal growth factor signaling by combinatorial receptor interactions. EMBO J. 1996; 15: 2452- 67.

6. Lee C.S. and Pirdas A. Epidermal growth factor receptor immune-reactivity in gall bladder and extrahepatic biliary tract tumours. Path Res Pract. 1995; 191:1087-91.

7. Kira S, Nakanishi T, Suemori S, Kitamoto M, Watanabe Y, Kajiyama G. Expression of transforming growth factor alpha and epidermal growth factor receptor in human hepatocellular carcinoma. Liver. 1997; 17: 17782.

8. Terada T, Ashida K, Endo K, Horie S, Maeta H, Matsunaga $\mathbf{Y}$, et al. c-erbB-2 protein is expressed inhepatolithiasis and cholangiocarcinoma.

Histopathology. 1998; 33: 32531.

9. Kondo Y, Kanai Y, Sakamoto M, Mizokami M, Ueda R, Hirohashi S.: Genetic instability and aberrant DNA methylation in chronic hepatitis and cirrhosis-A comprehensive study of loss of heterozygosity and microsatellite instability at 39 loci and DNA hypermethylation on $8 \mathrm{CpG}$ islands in microdissected specimens from patients with hepatocellular carcinoma.
Hepatology. 2000; 32(5): 97079.

10. Bieche I, Asselah T, Laurendeau I, Vidaud D, Degot C, Paradis V, et al.: Molecular profiling of early stage liver fibrosis in patients with chronic hepatitis $\mathrm{C}$ virus infection. Virology. 2005; 332(1): 130- 44.

11. Roncalli $M$, Bianchi $P$, Bruni $B$, Laghi L, Destro A, Di Gioia S, et al.: Methylation framework of cell cycle gene inhibitors in cirrhosis and associated hepatocellular carcinoma. Hepatology. 2002; 36(2): 42732.

12. Edamoto Y, Hara A, Biernat W, Terracciano L, Cathomas G, Riehle HM, et al.: Alterations of RB1, p53 and Wnt pathways in hepatocellular carcinomas associated with hepatitis C, hepatitis B and alcoholic liver cirrhosis. Int J Cancer. 2003; 106(3): 334- 41.

13. Korsmeyer S.J:. Bcl-2 gene family and the regulation of programmed cell death. Cancer Res. 1999; 59: 1693S - 1700S.

14. Takahashi M., Saito H., Okuyama T., Miyashita T., Kosuga M., Sumisa F., et al:. Overexpression of bcl-2 protects human hepatoma cells from Fasantibody-mediated apoptosis. J Hepatol. 1999; 31: 315- 22.

15. Huang Y.L., Chou C.K.:. Bcl-2 blocks apoptotic signal of transforming growth factor -beta in human hepatoma cells. J Biomed Sci. 1998; 5: 185- 91.

16. Tang Z.: Recent advances in clinical research of hepatocellular 
carcinoma in China. Chin Med J. 1995; 108: 568- 70.

17. Yildiz L., Baris S., Aydin O., Kefeli M., Kandemir B.: Bcl-2 positivity in $\mathrm{B}$ and $\mathrm{C}$ hepatitis and hepatocellular carcinomas. Hepatogastroenterology. 2008; 55(88): 2207-10.

18. Schaefer KL, Brachwitz K, Wai DH, Braun Y, Diallo R, Korsching $\mathbf{E}$ etal., Expression profiling of $\mathrm{t}(12 ; 22)$ positive clear cell sarcoma of soft tissue cell lines reveals characteristic upregulation of potential new marker genes including ERBB3. Cancer Res. 2004 May 15;64:3395-405

19. Zekri AR, Bahnassy AA, Abdel-Wahab SA, Khafagy MM, Loutfy SA, etal., Expression of pro- and antiinflammatory cytokines in relation to apoptotic genes in Egyptian liver disease patients associated with HCV-genotype4.J Gastroenterol Hepatol. 2009 Mar;24(3):416-28. Epub 2008 Nov 27.

20. Sanidas E.E., Filipe M.I., Linehan J., Lemoine N.R., Gullick W.J., Rajkumar T.et al.: Expression of the c-erbB-3 gene product in gastric cancer. Int J Cancer. 1993; 54: 935- 40.

21. Travis A, Pinder S.E., Robertson J.F.R., Bell J.A, Wencyk P., Gullick W.J, et al.: C-erbB-3 in human breast carcinoma: expression and relation to prognosis and established prognostic indicators. Br J Cancer. 1996; 74: 229 - 33.

22. Haugen D.R.F., Akslen L.A., Varhaug J.E., Lillehaug J.R.:.
Expression of c erbB-3 and cerbB-4 proteins in papillary thyroid carcinomas. Cancer Res. 1996; 56: 1184-88.

23. Qin L.X., Tang Z.Y. :The prognostic molecular markers in hepatocellular carcinoma. World J Gastroenterol. 2002; 8(3): 385 92.

24. Jain $S$, Singhal $S$, Lee $P, X u R$. Molecular genetics of hepatocellular neoplasia. Am J Transl Res. 2010; 2(1): 105-18.

25. Kapitanovic S., Radosevic S., Slade N., Kapitanovic M., Andelinovic S., Ferencic Z.et al.: Expression of erbB-3 protein in colorectal adenocarcinoma: correlation with poor survival. J Cancer Res Clin Oncol. 2000; 126: 205-11.

26. YIto, T Takeda, M Sakon, M Tsujimoto, $\mathbf{S}$ Higashiyama, $\mathbf{K}$ Noda, et al.: Expression and clinical significance of erb-B receptor family in hepatocellular carcinoma. Br J Cancer. 2001; 84(10): 1377-83.

27. Jun Cui, Bao-Wei Dong, Ping Liang, Xiao-Ling Yu, De-Jiang Yu.: Construction and clinical significance of a predictive system for prognosis of hepatocellular carcinoma World J Gastroenterol. 2005; 11(20): 3027 - 33.

28. El Bassuoni M.A., Talaat R.M., Ibrahim A.A., Shaker O.T.: TGF-beta1 and C-erb-B2 neu oncoprotein in Egyptian $\mathrm{HCV}$ related chronic liver disease and hepatocellular carcinoma patients. Egypt J Immunol. 2008; 15(1): 39 - 50 . 
29. Yang L, Si X, Wang W.: Overexpression of bcl-2 protects hepatoma cell line HCC-9204 from ethanol-induced apoptosis. Chin Med J. 2002; 115(1): 8-11.

30. Nakopoulou L, Stefanaki K, Vourlakou C, Manolaki N, Gakiopoulou H, Michalopoulos G.: Bcl-2 protein expression in acute and chronic hepatitis, cirrhosis and hepatocellular carcinoma. Pathol Res Pract. 1999; 195(1): 19-24.

31. Tsamandas AC, Thomopoulos K, Gogos C, Tepetes K, Kourelis T, Ravazoula $P$, et al. Expresssion of bcl-2 oncoprotein in cases of acute and chronic viral hepatitis type $\mathrm{B}$ and type $\mathrm{C}$ : a clinicopathologic study. Dig Dis Sci. 2002; 47(7):1618-24.

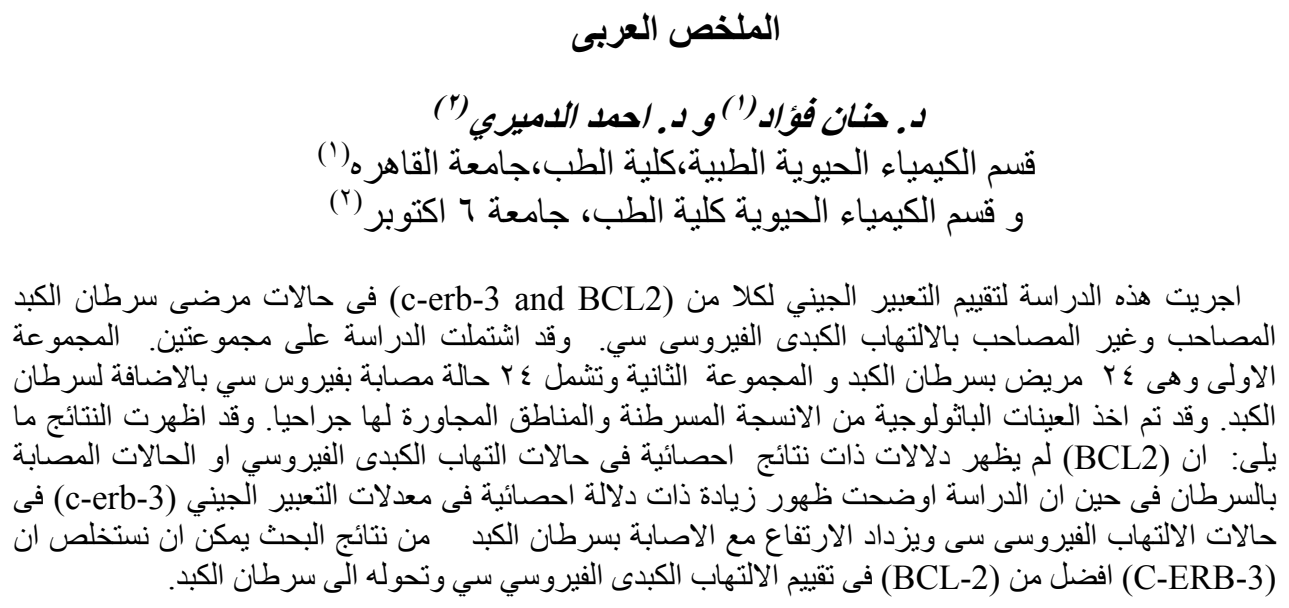

